\title{
Reviewer Acknowledgements for Global Journal of Health Science, Vol. 12, No. 1
}

Global Journal of Health Science wishes to acknowledge the following individuals for their assistance with peer review of manuscripts for this issue. Their help and contributions in maintaining the quality of the journal are greatly appreciated.

Global Journal of Health Science is recruiting reviewers for the journal. If you are interested in becoming a reviewer, we welcome you to join us. Please contact us for the application form at: gjhs@ccsenet.org.

\section{Reviewers for Volume 12, Number 1}

Abiodun Adeniran, University of Ilorin, Nigeria

Ahmed Hassan Ghada, Menoufia University, Egypt

Ayesha Johnson, University of South Florida, United States of America

Darampal Dambhare, Mahatma Gandhi Institute of Medical Sciences, India

David Otieno Odongo, Masinde Muliro University of Science and Technology, Kenya

David Richard Walwyn, University of Pretoria, South Africa

Fengsong Gao, The University of Queensland, Australia

France Ncube, Bindura University of Science Education, Zimbabwe

Gabriel Gulis, University of Southern Denmark, Denmark

Gavric Zivana, University Banja Luka, Bosnia and Herzegovina

Hadii M Mamudu, East Tennessee State University, United States of America

Hülya YARDIMCI, Ankara University, Turkey

Jaime Hinzpeter, Clinical Hospital University of Chile, Chile

Jason Tsai, Lincoln College, United Kingdom

Jingxian Cai, ICSA, ASA, ENAR, United States of America

Kartheek R Balapala, University Tunku Abdul Rahman, Malaysia

Kinley Wangdi, Australian National University, Australia

Madhu M. Ouseph, Brown University, United States of America

Meng Zhao, Texas A\&M University at Corpus Christi, United States of America

Pi-Ming Yeh, Missouri Western State University, United States of America

Polly Yeung, Massey University, New Zealand

Robert Sloan, Kagoshima University Graduate School of Medical and Dental Sciences, Japan

Roger Ho, National University of Singapore, Singapore

Sá Giulian César, Universidade Federal do Rio Grande do Norte, Brazil

Samir Othman, Hawler Medical University, Iraq

Valery Piacherski, Mogilev Regional Hospital, Belarus 